> "Now, the sense is that individuals really need to have more directed education."

Graduate students and postdocs, under pressure to publish and seek funding, have little time to learn non-research skills to boost their competitiveness. But employers - especially in industry - want recruits to have those skills. "If you have waited until year five of your postdoc and you think you are going to break into industry as a 'plan B',' says Sibby Anderson-Thompkins, director of postdoctoral affairs at the University of North Carolina at Chapel Hill (UNC), "it may not happen."

So universities around the world are setting up schemes to teach transferable and soft skills. These might involve hour-long lectures, half-day seminars or hands-on, activity-based experiences that offer aspiring researchers advice and training on how to run a lab, create a budget, write a paper, collaborate with colleagues and, of course, deliver a good talk. But not all workshops provide useful or practical advice that is worth a fledgling scientist's time.

\section{INFORMED DECISIONS}

Early-career researchers looking for workshops should start on campus. Cathee Johnson Phillips, executive director of the US National Postdoctoral Association (NPA) in Washington DC, says that soft-skills training is now available at more than 135 offices or associations of postdoctoral affairs in the United States, as well as hundreds of career-development offices at universities and research institutions in the United States and Europe. The NPA itself organizes an annual meeting with workshops on a range of topics: everything from conflict resolution to English for postdocs. One seminar at this year's meeting, called 'Business Dining is Not About Food', taught etiquette for business lunches and dinners.

Once they have picked a provider, researchers must choose which workshops to attend. "It depends on what you want to get out of it," says Jill Hurst, a pharmaceutical and biochemical sciences postdoc at the UNC. "For students and younger postdocs trying to figure out which way they are going to go career-wise, a more formal, this-is-what-is-available panel discussion works well." For in-depth inquiries, it might be preferable to attend a lunch seminar with an industry representative, for example, says Hurst. The seminar format gives researchers a chance to ask probing questions and improve their sense of what day-to-day working lives are like in industry.

Some institutions offer more extensive experiences. Stephen Fuchs, a biochemist at Tufts University in Medford, Massachusetts, attended a leadership training course at Cold Spring Harbor Laboratory in New York. There, he and a select group spent three days listening, discussing and role-playing. "It was intense and focused," Fuchs recalls. "And everybody there was looking for the same types of things." Those included tips on negotiating salary and

position, managing personnel and dealing with difficult conversations in the lab.

The specificity made it the best training experience that Fuchs has ever had, he says. To assess just how focused a workshop will be, prospective attendees can contact organizers and find out what motivated them to put the workshop together. For example, if a company representative is giving a talk with the intention of recruiting scientists for certain positions, the event might not be a great choice for a firstyear postdoc who simply wants to know more about working in industry. A panel discussion by industry experts would be a better fit.

Some misses can't be predicted. While still a postdoc at the UNC, Fuchs attended a seminar on the responsible conduct of research at the US National Institutes of Health (NIH) in Bethesda, Maryland. Speakers lectured on issues of authorship, data fabrication and conflict of interest. The seminar was mandatory for researchers who wanted to obtain federal funding, but it felt too "philosophical" to Fuchs, more a reflection on ethics than a guide to being a responsible researcher.

Scientists need practical guidance, says Fuchs. So he organized his own workshop on the subject at the UNC, and made sure that it

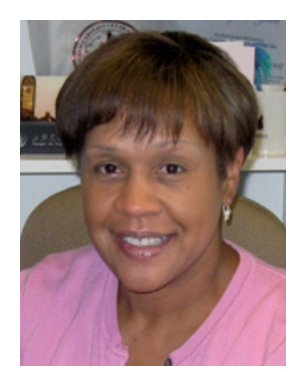

"It is amazing, the lack of selfawareness I

see."

Sibby AndersonThompkins

now held regularly.
Early-career scientists should keep an eye out for active rather than passive events, so that they can practise the skills of interest rather than merely discussing them. Dara Wilson-Grant, associate director of postdoctoral affairs at the UNC, held a workshop on networking, tied to an actual campus networking event with industry representatives. Workshop participants first listened to tips on networking, then role-played with each other and finally tried their luck at the event. Hurst attended and found the workshop so helpful that she landed a job interview that led to an offer after chatting with a science writer from a local biotechnology firm. "I learned how to ask good questions and get a sense of what the company was like," she says. "A year ago, I wouldn't have been able to do that."

Before attending a workshop, scientists can research the speaker's expertise and style to ensure that they are a good fit. Dahlben's favourite thing about Maratos-Flier's workshop was her demeanour. By presenting herself as a seasoned researcher who had experienced the same travails as the audience and overcome them, Maratos-Flier had credibility with her audience, says Dahlben.

\section{POCKETS OF RESISTANCE}

Despite the need and opportunities for softskills training, not everyone is enthusiastic. Some see workshops as irrelevant or unnecessary. "In terms of giving a talk, I have participated in many conferences," says Bernard Charlier, a geosciences postdoc at the Massachusetts Institute of Technology in Cambridge. "I have seen very good presentations and very, very bad. So, I learn from those."

But it may not be possible to learn enough by imitation in today's competitive environment. Critiques and feedback are crucial. "It is amazing, the lack of self-awareness I see," says Anderson-Thompkins. "People think, 'This isn't something I need a lecture on'. But I have seen it in action, with networking, for example. Postdocs clear a room because of the way that they are approaching people."

Some early-career scientists might want to attend workshops, but run into resistance from supervisors who prefer their charges to stay in the lab rather than investigate alternative careers. However, workshop organizers such as Paule Biaudet, a specialist in doctoral studies and employability at Pierre and Marie Curie University in Paris, argue that professional development helps not only students and postdocs, but also their principal investigators, who should support their lab members' training aspirations. She explains to mentors that the reputation of a lab is often linked to the career successes of the people who have been trained there. "Then the supervisors feel they must let the students go to the training," says Biaudet.

Good training ultimately opens doors in an increasingly challenging job market. MaratosFlier says that when she started out in research, "it would have been nice to have had somebody tell me in a non-judgemental way, 'you're doing this or that wrong', or a better or more effective way to do it. Now, you don't need to reinvent the wheel. Workshops can get you to a skill level you want to be at, without having to work it out all by yourself."

Trisha Gura is a freelance writer based in Boston, Massachusetts.

\section{CORRECTION}

The map in the story 'Excellence revisited' (Nature 487, 519-521; 2012) omitted the symbol to show that the University of Konstanz has received an award for 'future concepts'. The map has been corrected online at go.nature.com/rciac4. 